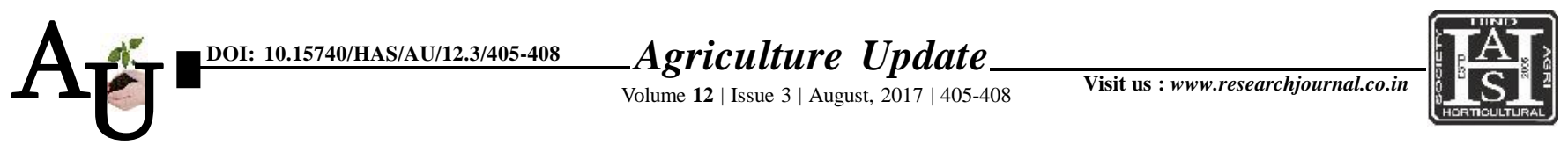

a ISSN-0976-6847

\title{
Research Article: Entrepreneurial behaviour of oil palm growers
}

\section{口 P.S.M. PHANISRI AND B. PARASAR}

Article Chronicle : Received :

24.05.2017;

Revised :

23.06.2017;

Accepted :

06.07.2017

\section{KeY WoRds:}

Entrepreneurial

behaviour, Oil palm

growers
Author for correspondence :

\section{P.S.M.PHANISRI}

College of Horticulture, VENKATARAMANNAGUDEM, Dr. Y.S.R. Horticultural University (A.P.) INDIA Email:madhumitha493@ gmail.com

See end of the article for authors' affiliations
SUMMARY : A study on entrepreneurial behaviour of oil palm growers in Khammam district of Andhra Pradesh was undertaken in 5 mandals with 100 respondents selected at random to find out the entrepreneurial behaviour of respondents. The data were collected through structural interview schedule. Majority (28\%) respondents educated upto +2 level, 91 per cent belonged to general category under prevailing caste system of the respondents. Further majority (39\%) of the respondents were in $46-44$ age group with the land holding 5-10 acres (46\%), above Rs. 2,00,000 annual income (70\%). In relation with various components of entrepreneurial behaviour, majority (68\%) belonged to medium level of innovativeness followed by (74\%) equal for both economic motivation and communication skills and 75 per cent, 72 per cent, 71 per cent, 67 per cent, 62 per cent, medium level of risk orientation, information seeking, achievement motivation, decision making ability, self confidence, respectively and all the respondents had high level of management orientation.

How to cite this article : Phanisri, P.S.M. and Parasar, B. (2017). Entrepreneurial behaviour of oil palm growers. Agric. Update, 12(3): 405-408; DOI : 10.15740/HAS/AU/12.3/405-408. 